\title{
Critical Theory-Based Approaches in Geography Teaching Departments in Turkey
}

\author{
Münür Bilgili \\ Correspondence: Münür Bilgili, Marmara University, Atatürk Education Faculty, Department of Geography Teaching, \\ Turkey.
}

Received: December 28, 2017

doi:10.11114/jets.v6i2.2956
Accepted: January 24, $2018 \quad$ Online Published: January 27, 2018

URL: https://doi.org/10.11114/jets.v6i2.2956

\begin{abstract}
The aim of this study is to understand the relationships between critical theory-based approaches and its implementations in geography teaching departments in Turkey. Critical theory dates back to 1930s and has developed over time aiming to deal with institutions, culture and society through critical lens. Currently, critical theory-based research designs and research paradigms inspire a large number of books, articles especially in qualitative researches due to their beneficial outcomes for the vulnerable, the poor and the othered segments of society with which critical researches are mainly concerned.

In the study, firstly it was described critical theory and critical research characteristics. Secondly, human geography and critical research relationships covered. Thirdly, human geography courses in geography teaching departments in Turkey explained in connection with critical theory. The relationships between these courses, critical theory and critical research were tried to explore. The study emphasized the importance of critical theory in courses in human geography considering far-reaching effects of critical theory on humanities, social sciences and art studies. Human geography has and should have close connections with other disciplines and sub-disciplines drawing on multiple theories, concepts and approaches.
\end{abstract}

Keywords: critical theory, critical research, geography teaching, geography course

\section{Approach and Method}

This study draws on critical theory and critical theory-inspired research paradigm and approach. These philosophical and theoretical inform the study. Critical research is oriented on power relations in society the critique of culture and institutions aiming to improves the lives of vulnerable peoples, groups or individuals. It includes participatory action researches (Merriam and Tisdell, 2015). The method of the study is document analysis. All course programs in geography teaching departments analyzed. This document analysis conducted with interpretive and critical approach focusing on different parts of the courses on human geography.

\section{Critical Theory}

Critical theory is a term coined by Max Horkheimer in 1937 to describe the work of the Frankfurt School (Buchanan, 2010). From then on, its meaning and scope have begun to broaden gradually and now it is an umbrella term mainly used in social sciences, humanities and art studies. It sees the events, phenomena, developments and processes in social world with/through critical lens not basing them on meta-narratives and grand-theories which have firm ontological and epistemological foundations (Crotty, 1998). Meta-narratives could be generally found in positivism, Marxist theory or the Western-oriented Enlightenment.

Critical theory and researches tend to be found across all social disciplines blurring the discipline boundaries as drawing on multiple sources. Critical theorists learned to interpret the particular with an eye on the totality (Bronner, 2011). That's, theorist tries to see the particular in its totality and setting.

Critical theory does not mean to criticize everything or in Tyson's terms critical theory is not fault finding (Tyson, 2006) as its name may imply. It has developed mostly in reaction to modernism, meta-narrative, economic determinism in Marxist theory and foundationalism. It stands against foundationalist ontology, epistemology and methodology. Critical theory can be seen as precursor to postmodernism as Zuidervaart (2015) has suggested. Despite the time span between the two, they share many similar characteristics such as contextuality, historicity and theory-leadenness of any given phenomenon or explanation. 
Reality in critical theory is not anchored in positivist or scientific realism, because positivism and realism see reality something that should be beyond human subjectivity and interference. Scientific reality sees reality whatever science puts forward (Chakravartty, 2017). Critical theory regards this approach as illusion (Buchanan, 2010) and reality itself is context-bound and riddled with politics, culture, economy and ideology. All of them can have a role to play in reality construction. Therefore, there is no underlying, unique and sole reality from the critical point of view.

Critical theory has a recursive dimension using dialectics as a form of reasoning. It contains going back and forth in theory construction as researcher considers herself/himself constantly where she/he stands, how the surrounding processes and developments affect her/him and vice versa. Therefore, reality, human, knowledge, science and many other factors are closely interrelated and interconnected. It is impossible for us to get ourselves out of context and seeing such factors in an "untainted" way. As Haraway (1998) puts it we have not God's eye and view so all knowledge is situated reflecting its context and conditions in which it embedded.

Critical theories emerged in connection with many social movements (Bohman, 2016). They reject seeing theory and social life separated firmly from each other, on the contrary, they feed one another in constant manners. Hence, stance against theory and theorist's isolation from society, strong commitment to human well-being and rejection of firm determinism have given rise to new understandings and these understandings have found room in critical theory.

Before getting into new section focusing on critical research it is useful to note what critical theory means in short. Critical theory-based studies in any discipline share some similar leanings. Those leaning may vary from study to study or from discipline to discipline, but some common features can be summarized as follows;

- Anti-foundationalist

- Recursive and dialectic

- Against meta and grand theories

- Context-bound

- Process-oriented

- Mind-dependent

- Anti-determinist

- Focusing on power relations

- Anti-modernist

- Anti-essentialist

- Aiming at human emancipation

- Socially constructed realities and knowledge

- Interventionist in terms of theory and practice

\section{Critical Research}

As stated above critical theory firstly originated in the Frankfurt School and then it has developed into many paradigms, approaches, designs in social sciences and art studies. Critical theory-based research designs and methodologies are now strongly entrenched in social sciences as social researchers adopt core elements of this theory in their own ways. Many approaches, philosophical and theoretical positions are mostly being grouped under critical research, so any theory or paradigm related to social critique, society, culture come under the heading of critical research. For example, gender studies, social theory, postcolonialism, cultural studies, deconstruction, postmodernism, poststructuralism, feminist theory, Marxist theory, indigenous studies, psychoanalytic theory, structuralism are generally treated as critical theory-based theories, paradigms or approaches.

Critical researches focus typically on some common themes such as identities, social justice, emancipation, power relation in different scales and fields, otherness, indigenous rights, minority rights, women rights, gender issues, human rights and so on. These topics are treated through critical lens focusing on groups and peoples, which are more vulnerable to alienation, oppression and exploitation. The oppressed and their emancipation, making their voice heard, exposing ways of oppression to public and governing bodies are main objectives of critical researches. Those researches and researchers tend to ignore scientific-positivist objectivity, reject to researcher first-researched second relationships in studies, be opposed to searching for underlying and unchangeable reality. They do so, because either they do not believe them or see them unimportant as putting human amelioration first.

Critical theory has inspired critical research strategies and designs. These types of research designs include many theoretical underpinnings of critical theory as is said above. For Merriam and Tisdell (2015), critical research focuses 
less on individuals than on context. Because we need to locate problems first in their context and structure that will be helping us to be aware of power relations already in work. Framing problems and contexts may be seen in some settings more important than finding solution to any problem considering multi-faceted and intricate social world.

Critical research tries to improve human lives (Creswell, 2014) as well as tries to combine theory and praxis (Brinkmann, 2017). Critical race theory, postcolonial theory, indigenous studies and many others are implicitly or explicitly involved in efforts aiming to enhance human life quality as researcher takes an active role especially in participatory-action researches. Researchers are more concerned with institutions and their roles in social relations that create unbalanced power relationships. Creswell (2012) says interpretation of social life, social struggles, domination and oppression covered generally in critical researches. Critical researches aim to empower the oppressed (Leavy, 2017). They do so by exposing the power relations, uneven development, widening income range between the rich and the poor in multiple ways.

Critical research's ontology is historical realism (Lincoln and Guba, 2016). This means that all social, economic, political and cultural values and norms have changed over time. We need to place them in their historical settings so as to frame and understand them truly, so historical background, context-bound characteristics and non-linearity of phenomena are intimately interrelated. Critical research's epistemology is in nature plural, historical, power-laden and co-constructed. Both ontology and epistemology converge on the historicity of the reality and knowledge. There are multiple approaches at this point. For example, Bohman (2016) offers methodological and theoretical pluralism in critical social research as Crotty (1998) emphasizes the need of being open to new ways of understanding. Pernecky (2016) stresses that critical theory has a place in pragmatist paradigm. All these citations have made clear the necessity of multiple ontology, epistemology and methodology in critical research.

\section{Human Geography and Critical Theory-Based Approaches}

Geography deals mainly with interactions between humans and the environment. It has been one of the most employed description of geographical discipline until now. This description seems not to be reflective of the current developments in geography or more broadly in social sciences considering the growing effects of human agency on the human-environment. We need a more elaborate understanding of those relations in differing contexts such as how humans construct their identities, how social spaces interact with each other, how spaces being reproduced, how and why different spaces emerge, how and in what ways human and the environment act on each other and so on. To understand and explain all that mentioned processes it is required multi-faceted approaches and views. For instance, Massey suggests that radical geography has still a place in connection with understanding social space and its implications. As she sees space as social production, she also emphasizes that it is need to reconceptualize space to understand all related interactions and effects (Massey, 20013). Similar lines can be found in Cresswell's researches on place (Cresswell, 2013, 2014).

Critical geography or more narrowly critical human geography is a generic term comprising many theories and approaches such as critical geopolitics, feminist geographies, postcolonial geographies, Marxist geography, postmodern geographies, critical cartography, poststructuralist geographies. All of them are related to, informed of, based on, stemming from critical theory. Geography has a growing literature on critical-centered studies and researches as many geographers assert that geography can and should lean on critical theory-inspired studies. Bilgili suggests that critical research-based poststructuralist theory and deconstruction have a potential to offer new insights on geography (Bilgili, 2017). Critical approaches from the oppressed point of view can be seen in many leading books on human geography and place/space-bound issues in Domosh, Rose, Harvey Sharp and McDowell's researches (Domosh, 1988; Rose, 1993; Harvey, 1996; McDowell and Sharp, 1997; McDowell, 2013) and in many other publications.

\section{Human Geography Courses in Geography Teaching Departments in Turkey}

Science changed and will continue to change over time as everything changes. Geography, especially human geography has changed and transformed since 1970s (Livingstone, 1992) as new problems and questions appear in the field such as minority rights, feminist movements, indigenous rights, developing ghettos for the othered and alienated people are strongly entrenched in human geography. These topics and many others in human geography are approached from place/space perspectives. Social spaces, production of space, gendered spaces, uneven development in rural and urban areas need such perspectives. As is indicated above there is a tremendous literature focusing on them.

Despite a significant gap in critical theory-leaning courses and resources in human geography in Turkey, there is a literature and studies dealing with immigration, globalizations, identity politics, refugees, poverty, security, otherness, social spaces and gentrification. Similar developments could be discerned in geography teaching. For instance, Ünlü's Geography Teaching book (Ünlü, 2014) covers many methodological problems in geography teaching with new perspectives. Another important source is Öztürk's book titled Research in Geography Education in which he emphasizes the importance of critical research in detail (Öztürk, 2014). Though these books signal developments in the discipline, there is still a large number of topics and aspects remain to be covered. There is no equal, overlapping and 
synchronize developments in human geography between Turkey and Western countries. It could be asserted rightly, at this point, that there will not be same developments in every country in any way. This is exactly true but it can be expected to keep pace with the advanced counterparts in the related disciplines and there will be comparison always.

Currently there are 7 geography teaching departments in Turkey (geography departments in Faculty of Arts and Sciences are not included in this study). These departments generally cover similar courses both in physical and human geography but as the study's name indicates we are going to focus on human geography courses, because critical theory-related subject, development, phenomenon, concept, paradigm and approach can be implemented in such contexts. Space, place, landscape studies perfectly fit in with critical theory-based paradigms. They can inform each other in different ways in different settings.

Geography teaching departments have a great deal of similarity in terms of course names and elective courses as is seen in the Table.1 below. Population Geography, Tourism Geography, Agricultural Geography, Economic Geography, Political Geography, Settlement Geography, Industrial Geography, Transportation Geography, Urban Geography are the most generic courses and many geographical topics have been covered under these courses. At this point it is necessary to underscore that names themselves are of little importance but at the same time they truly reflect the lack of new approaches, concepts and theoretical leanings in human geography. These courses indicate that classical geography teaching models are still being widely used in geography teaching.

Courses generally supplemented course books which have also similar tendencies with courses. These courses approached from descriptive point of view. Students have to remember a large number of place, name, country, energy resources covered under those lessons which prevent them from having different perspective and point of view.

There are some points to make in the process of conducting critical theory-based studies and courses. First, we should pick questions and issues out for studying and why to do so. We need to locate those issues in their right places and settings, because the problem description and context are of great importance to any given study not only for geography. Second, after delineating the subject and related phenomena we need to adopt an approach or related philosophical-theoretical dimension. Third, as is put forward in the study there is a gap in courses and approaches in geography teaching departments. But all those courses do not reflect current developments in social sciences and humanities drawing largely on critical theory.

As is shown in the Table.1 you can see some developments concerned with critical stance in courses. For instance, Social Geography, Health Geography, Cultural Geography reflect the renewing understandings in geography as these courses allow us to deal with issues from critical perspectives. Despite modest developments we need to renew, develop and devise new courses and programs reflecting current thinking in social sciences. Surely, departments have not to share same courses and understanding, on the contrary, they should be reflective of plurality, diversity and range regarding the topics and courses they cover.

Space and place, gender issues, postcolonial geographies, poststructural geographies, critical geography, spatial analysis, cognitive geography, postmodern geographies, feminist geographies, critical geopolitics are generally eschewed or missed in geography teaching programs. We need to adopt rigorous analysis, critical approaches, diverse understanding.

Table 1. Geography Teaching Departments and Human Geography Courses in Undergraduate Programs

\begin{tabular}{|c|c|c|c|c|c|c|c|}
\hline \multirow[b]{2}{*}{ Courses } & \multirow[b]{2}{*}{$\begin{array}{l}\text { Marmara } \\
\text { Uni }\end{array}$} & \multirow[b]{2}{*}{ Gazi Uni } & \multicolumn{5}{|c|}{ University Names } \\
\hline & & & $\begin{array}{l}\text { Dokuz } \\
\text { Eylül Uni }\end{array}$ & $\begin{array}{l}\text { Çanakkale } \\
18 \text { Mart }\end{array}$ & $\begin{array}{l}\text { Necmettin } \\
\text { Erbakan }\end{array}$ & Dicle Uni & Atatürk Uni \\
\hline Population Geo & $\mathrm{X}$ & $\mathrm{X}$ & & $\mathrm{X}$ & $\mathrm{X}$ & $\mathrm{X}$ & \\
\hline Economic Geo & $X$ & $\mathrm{X}$ & $X$ & & $\mathrm{X}$ & $\mathrm{X}$ & $\mathrm{X}$ \\
\hline Agricultural Geo & $\mathrm{X}$ & & & $\mathrm{X}$ & & $\mathrm{X}$ & \\
\hline Political Geo & $\mathrm{X}$ & $\mathrm{X}$ & $\mathrm{X}$ & $\mathrm{X}$ & $\mathrm{X}$ & & \\
\hline Urban Geo & $X$ & $X$ & & $X$ & & & $\mathrm{X}$ \\
\hline Settlement Geo & $X$ & $\mathrm{X}$ & $\mathrm{X}$ & $\mathrm{X}$ & $\mathrm{X}$ & $\mathrm{X}$ & $\mathrm{X}$ \\
\hline Industrial Geo & & $\mathrm{X}$ & $X$ & & & $\mathrm{X}$ & $\mathrm{X}$ \\
\hline Energy Geo & $\mathrm{X}$ & $\mathrm{X}$ & $\mathrm{X}$ & $X$ & & & \\
\hline Transportation & $X$ & $X$ & & $X$ & & & \\
\hline Geo & & & & & & & \\
\hline Social Geo & & $\mathrm{X}$ & & & & & \\
\hline Spatial Planning & & $\mathrm{X}$ & & & & & \\
\hline Tourism Geo & $X$ & $X$ & & $\mathrm{X}$ & & & $\mathrm{X}$ \\
\hline Cultural Geo & $X$ & $X$ & $X$ & $X$ & & $\mathrm{X}$ & $\mathrm{X}$ \\
\hline Regional Geo & $\mathrm{X}$ & $\mathrm{X}$ & $\mathrm{X}$ & & $\mathrm{X}$ & & $\mathrm{X}$ \\
\hline Health Geo & $X$ & $\mathrm{X}$ & & & & & \\
\hline
\end{tabular}




\section{Conclusion and Suggestions}

Critical theory-based approaches add new insights, dimensions, views to studies. They can enhance and enrich our understanding and explanations with renewed and broadened theoretical underpinnings. But this study shows that in courses in geography teaching departments in Turkey there is gap that is not representing current developments in social sciences despite some advancements such as the courses Social Geography in Gazi University and Health Geography in Marmara and Gazi University.

It can be drawn some conclusions from the study as follows; Geography teaching department largely lack new insights into social sciences particularly critical theory. Teaching department courses are overwhelmingly similar. This is an obstacle to diversity and plurality in the discipline. Similar courses have continued to be taught for decades with same content, although social sciences adopt new ways of thinking, theorizing, analyzing and synthesizing with critical outlook.

Considering the conclusion of the study, we can offer some suggestions on the issue. First, it needs to overhaul human geography courses making elaborate changes. Second, these changes must represent current developments related to critical theory and research. Third, there is a need to remove some courses which focus heavily on description and name-place remembering reminiscent of outdated learning and teaching models and the replace these courses with new ones that are reflective of mentioned developments. Fourth, all of us should be open to communication, inform ourselves of current thinking and theorizing in science.

\section{Bibliography}

Bilgili, M. (2017). Coğrafyanın bilimsel kimliğine postyapısalcı bir yaklaşım. Marmara Coğrafya Dergisi, 35, 101-109. https://doi.org/10.14781/mcd.291173

Bohman, J. (2016). "Critical Theory", The Stanford Encyclopedia of Philosophy (Fall 2016 Edition), Edward N. Zalta (ed.), URL = <https://plato.stanford.edu/archives/fall2016/entries/critical-theory/>.

Brinkmann, S. (2017). Philosophies of Qualitative Research (Understanding Qualitative Research). Oxford University Press.

Bronner, S. E. (2011). Critical Theory: A Very Short Introduction Oxford University Press.

Buchanan, I. (2010). A Dictionary of Critical Theory (Oxford Quick Reference). OUP Oxford.

Chakravartty, A. (2017). "Scientific Realism", The Stanford Encyclopedia of Philosophy (Summer 2017 Edition), Edward N. Zalta (ed.), URL = <https://plato.stanford.edu/archives/sum2017/entries/scientific-realism/>.

Cresswell, T. (2013). Geographical Thought, A Critical Introduction, Wiley-Blackwell.

Cresswell, T. (2014). Place: An Introduction. Wiley.

Creswell, J. W. (2012). Qualitative Inquiry and Research Design: Choosing Among Five Approaches. SAGE Publications.

Creswell, J. W. (2014). A Concise Introduction to Mixed Methods Research (Sage Mixed Methods Research). SAGE Publications.

Crotty, M. J. (1998). The Foundations of Social Research: Meaning and Perspective in the Research Process. SAGE Publications.

Domosh, M. (1988). Geography and gender: home, again? Progress in Human Geography, 22, $276-82$. https://doi.org/10.1191/030913298676121192

Haraway, D. (1998). Situated Knowledges: The Science Question in Feminism and the Privilege of Partial Perspectives", in Feminist Studies, 1988, pp. 575-599.

Harvey, D. (1996). Justice, Nature and the Geography of Difference. Oxford: Blackwell.

Leavy, P. (2017). Research Design: Quantitative, Qualitative, Mixed Methods, Arts-Based, and Community-Based Participatory Research Approaches (p. 11). Guilford Publications.

Lincoln, Y. S., \& Guba, E. G. (2016). The Constructivist Credo. Taylor and Francis.

Livingstone, D. N. (1992). The Geographical Tradition: Episodes in the History of a Contested Enterprise. Oxford: Blackwell.

Massey, D. (2013). Space, Place and Gender, Wiley.

McDowell, L. (2013). Gender, Identity and Place: Understanding Feminist Geographies (p. 254). Wiley. 
McDowell, L., \& Sharp, J. (eds) (1997). Space, Gender, Knowledge: Readings in Feminist Geography. London: Arnold.

Merriam, S. B., \& Tisdell, E. J. (2015). Qualitative Research: A Guide to Design and Implementation (Jossey-Bass Higher \& Adult Education Series). Wiley. https://doi.org/10.4018/978-1-4666-7409-7.ch007

Öztürk, M. (2014). Coğrafya Eğitiminde Araştırma, Ankara, Pegem.

Pernecky, T. (2016). Epistemology and Metaphysics for Qualitative Research. SAGE Publications. https://doi.org/10.4135/9781473982956

Rose, G. (1993). Feminism and Geography: The Limits of Geographical Knowledge. Cambridge: Polity Press.

Tyson, L. (2006). Criticial Theory Today: A User Friendly Guide, Second Edition. Routledge.

Ünlü, M. (2014). Coğrafya Öğretimi. Ankara. Pegem Akademi.

Zuidervaart, L. (2015). "Theodor W. Adorno", The Stanford Encyclopedia of Philosophy (Winter 2015 Edition), Edward N. Zalta (ed.), URL = <https://plato.stanford.edu/archives/win2015/entries/adorno/>.

\section{Internet Sites}

http://debis.deu.edu.tr/ders-katalog/2014-2015/tr/bolum_1096_tr.html

http://www.dicle.edu.tr/ziya-gokalp-egitim-fakultesi_-orta-ogretim-sosyal-alanlar-bolumu-cografya-egitimi

http://sbte.egitim.comu.edu.tr/viewer

https://www.konya.edu.tr/storage/images/department/ahmetkelesogluegitim/duyuru/derskod2015_16/CO\%C4\%9ERAF

YA\%20(4\%20YILLIK).pdf

http://meobs.marmara.edu.tr/ProgramTanitim/ataturk-egitim-fakultesi/lisans-1061-6

http://gef.gazi.edu.tr/posts/view/title/anabilim-dallari-ders-kodlari-71539

http://www.dicle.edu.tr/ziya-gokalp-egitim-fakultesi_-orta-ogretim-sosyal-alanlar-bolumu-cografya-egitimi

https://atauni.edu.tr/yuklemeler/5d22e68c823d2f8300e937103ecae221.pdf

\section{Copyrights}

Copyright for this article is retained by the author(s), with first publication rights granted to the journal.

This is an open-access article distributed under the terms and conditions of the Creative Commons Attribution license which permits unrestricted use, distribution, and reproduction in any medium, provided the original work is properly cited. 